took over publication and by 1941, when Raymond Pearl died, Human Biology was gaining ground in many fields of interest, but particularly human evolution, primatology, growth and demography. The following years proved more difficult, but under the successive editorship of Lowell Reed, Charles Winsor and William Cochrane the journal survived the war years. In 1953 a new board of editors was appointed. Timely support from the WennerGren Foundation for Anthropological Research and the National Science Foundation and transfer of publication to the Wayne State University Press ended the threatened demise of the publication.

For some time the journal has had an international tone. Within recent years Human Biology has reported research conducted in Guatemala, Mexico, Brazil, Peru, South Africa, Liberia, Nigeria, New Guinea, Poland, Czechoslovakia, Yugoslavia, Hungary, Spain, Sweden, Korea, Hong Kong and Japan, as well as Great Britain, Canada and the United States. Human biology deals with man everywhere and it is hoped that, with the new wider base of support from the Society, the journal will reflect this in contributions from all regions of the world.

The editor-in-chief is Dr. Gabriel W. Lasker, Department of Anatomy, Wayne State University, College of Medicine, Detroit, Michigan, and the editor for the Society is Dr. J. M. Tanner, Department of Growth and Development, University of London Institute of Child Health, the Hospital for Sick Children, Great Ormond Street, London, W.C.1.

\section{The Science Library Bibliographical Series}

Recent issues in the Science Library Bibliographical Series, Nos. 782-784, deal with: lipids in lungs (No. 782: Lipids in Lungs - a Literature Search on Lipids in the Lungs of Vertebrates, including Man. Pp. 5. 1s.); vibration (No. 783: Vibration-Selected References on the Response of Human Beings to Vibration and its Clinical Effects. Pp. 4. 1s.)-this (No. 783) is a supplement to No. 695; and tropical rain forests (No. 784: Tropical Rain Forests. Pp. 7. 1s.6d.), which is a supplement to No. 681. Copies are available from the Science Museum, Exhibition Road, London, S.W.7.

\section{The American Philosophical Society}

THE Year Book for 1962 of the American Philosophical Society includes, besides the list of officers and committees for 1962-63, reports of standing committees, lists of publications and of members and a brief history of the Society by E. G. Conklin (Pp. 790. Philadelphia: American Philosophical Society, 1963). It also contains biographical memoirs, among which are those of P. W. Bridgman, A. H. Compton, Hu Shih and G. M. Trevelyan. Of the 790 pages, more than 400 are occupied by the report of the Committee on Research which, besides a list of grants during the year totalling 186,000 dollars (191 grants) from the Penrose Fund and 64,000 dollars (67 grants) from the Johnson Fund, includes brief accounts of the work of the recipients.

\section{Rock Carvings and the Late Dr. P. Harper-Kelley}

THE occurrence of rock carvings is well-nigh universal. They are common in parts of South Africa, and indeed in many other regions of that continent. They have been found in America, Europe, Asia and Australia. Why primitive folk should have wished to make engravings on rock surfaces remains largely a mystery, and we must not assume that only one motive operated. In the April issue of Man, Prof. Kosambi directs attention to yet another series of deeply engraved rocks near Poona (India). The grooves sometimes reach a depth of $2 \mathrm{~cm}$ and were rubbed smooth to a semi-circular cross-section. The figures are mostly patterns, though a few may be derived from animal shapes. Concentric circles occur, and in one or two cases a small chalcedony nodule forms the centre of the innermost circle. Perhaps here, too, an animal eye with central pupil may have been intended ? In the vicinity of the engraved rocks there is an ancient necropolis; as some of the engraved rocks have been used in the construction of the graves they must be anterior in date to the necropolis itself. This Poona series is of considerable interest and one can only be glad that they have now been put on record. In the same issue of Man, Dr. Henry Field gives a short obituary of the late 'Pat' Harper-Kelley. Many years ago Kelley settled in Paris and became interested in early archæology. He worked at one time with the late Abbé Breuil and undertook not a little research in connexion with Old Stone Age cultures. For many years he held a post at the Musée de l'Homme. He will leave a gap in the ranks of prehistorians working in France.

\section{A Modern Magmatic Ore Solution ?}

A weLl drilled for geothermal power to a depth of $5,232 \mathrm{ft}$. in the Salton Sea region of California has resulted in geochemical discoveries of quite unusual interest, a preliminary account of which has been given by Dr. D. E. White, E. T. Anderson and D. K. Grubb in a recent issue of Science $(139,919 ; 1963)$. This is the world's deepest well in a high-temperature hot-spring province, with depth temperatures in the range $270^{\circ}-370^{\circ} \mathrm{C}$. It taps a very saline brine of $\mathrm{Na}-\mathrm{Ca}-\mathrm{K}-\mathrm{Cl}$ type (about 185,000 p.p.m. chlorine), with exceptionally high content of potassium $(23,800$ p.p.m.) and with perhaps the highest content of minor alkali elements known for natural waters; and it is believed that this brine may derive from the same magma chamber as furnished the late Quaternary rhyolite domes of the region, representing an undiluted magmatic water residual after the separation of a more volatile phase represented by near-surface hot-spring manifestations. During a three-month production test, several tons of material precipitated in the discharge pipe, this deposit consisting dominantly of amorphous silica with iron and manganese, and abundant bornite. Chemical analyses reveal the astonishingly high content of about 15 per cent copper, 2 per cent silver, and notable arsenic, bismuth, lead, antimony, and some minor elements. The brine may therefore be the first example of an 'active' magmatic ore solution. Drill cores from 4,400 to $5,000 \mathrm{ft}$. depth contain chlorite, albite, epidote, mica and quartz, with some indication of increase of metamorphic grade downwards, suggesting that the young sedimentary rocks are undergoing contemporary metamorphism. The economic potential of the discoveries has resulted in the operation being 'staked' as a possible ore deposit. Gedchemical investigations of the brine and drill cores are being continued by Dr. D. E. White, of U.S. Geological Survey, whose earlier studies on the chemistry of ground-waters and of epithermal ore deposits are widely known.

\section{Rabbit Control}

The Agricultural Research Liaison Section and the Division of Wildlife Survey of the Commonwealth Scien. tific and Industrial Research Organization. Australia, has issued a leaflet setting out the position regarding the rabbit pest (Rabbit Control. Pp. 8. Melbourne: Commonwealth Scientific and Industrial Research Organization, 1962). This is an important document because it provides a considered and authoritative account of what aro the results of the myxomatosis complex in Australia and what might happen if, in a spirit of lethargy, the rabbit were to be allowed to multiply; and what can be dono if advantage is taken of tho existing low population in order to control the situation. Myxomatosis has not controlled the rabbit population, though it has caused such a reduction that means for dealing with it are within reach. Landowners are urged to act in co-operation with the local bodies that can give assistance; all-important is that measures taken should be sound and organized. Control is now not primarily a scientific research problem. 